\section{Congress reviews DNA testing}

\section{Washington}

Bills to regulate the forensic use of DNA fingerprinting are expected to be introduced into both houses of Congress this week.

The proposed legislation aims to address widespread concern, expressed by defence lawyers and some academic biologists, about the quality of DNA evidence now coming before US courts.

The bills, drafted by Don Edwards (Democrat, California) in the House and Paul Simon (Democrat, lllinois) in the Senate, would make federal funds available to state and local crime laboratories conducting DNA testing. The director of the Federal Bureau of Investigation (FBI), advised by a permanent independent advisory panel, would draw up standards for DNA testing, and those standards would bind the central forensic laboratory of the FBI as well as any laboratories that take federal funding. The proficiency of each scientist producing DNA fingerprints in these laboratories would be tested at least twice a year.

At present, there are no legally binding standards to assure the quality of DNA fingerprinting evidence, which is now being produced by the FBI, 13 state and local laboratories and two main commercial DNA testing laboratories, Cellmark Diagnostics of Germantown, Maryland and Lifecodes, of Valhalla, New York.

The proposed legislation would not apply to the commercial laboratories, nor to any state and local laboratories choosing not to apply for federal funds. But once standards are published, courts are likely to demand that any laboratory submitting evidence obey the standards and subject itself to the same proficiency testing proposed for government-funded crime laboratories.

The need for published standards is generally accepted by forensic DNA testing practitioners. Kevin McElfresh, director of identity testing at Lifecodes, says the lack of standards can be used by defence lawyers as a weapon to challenge DNA evidence.

Although DNA evidence has been accepted by most courts in which it has been presented, DNA fingerprints have been ruled inadmissible in a handful of celebrated cases. But biologists who have testified as expert witnesses for the defence in cases involving DNA evidence argue that tighter regulation is needed for a more sinister reason - the possibility that sloppy laboratory work could result in the innocent being convicted of murder or rape, or the guilty going free. Robyn Nishimi, the author of a congressional Office of Technology Assessment report on forensic DNA testing published_last_year (ses. Nature. 34h, 4.99; 1990), agrees: "It's not just an admissibility in court issue, it's a quality of data issue." Problems can arise in DNA fingerprinting when initial digestion of DNA using restriction enzymes is incomplete, or if the electrophoresis condi- tions used to separate the DNA fragments vary.

These errors can often be spotted, but simpler mistakes - such as the mislabelling of sample tubes, or cross-contamination from one sample to another - can slip through unnoticed. Simon Ford, a California-based biotechnology consultant who has acted as an expert defence witness in cases involving DNA testing, points to the results of one of the few published DNA fingerprinting proficiency tests. In 1987 and again in 1988, the California Association of Crime Laboratory Directors sent Cellmark 50 samples to fingerprint and to group those that matched. On both occasions, Cellmark came up with one false match.

Many population geneticists are critical of the methods used by forensic laboratories to calculate the probability of an observed match between DNA profiles occurring by chance. Dan Hartl, from Washington University, St Louis, believes that the probabilities quoted in court "can easily be off by a factor of a thousand". The problem is that forensic scientists usually ignore the substructuring within Caucasian, black and Hispanic populations. Within population subgroups, band sharing on DNA fingerprints may be much more common than for the population as a whole.

Edwards' draft bill calls for a permanent independent advisory board, including molecular geneticists, population geneticists and legal experts, to be set up by the National Institute of Standards and Technology to develop standards for forensic DNA testing and to advise the director of the FBI. The involvement of academics and lawyers is not to the liking of all forensic scientists. But Eric Lander, from the Whitehead Institute at the Massachusetts Institute of Technology, who has taken a high profile in the debate over forensic DNA testing (see Nature 339, 501; 1989 ), says that academic participation is essential. "This is an issue of the transfer of technology from academia to forensics," he says. The bill also contains clauses to ensure that DNA test data identifying an individual are obtainable only by criminal justice agencies and the defendant.

In drafting their bills, Edwards and Simon have jumped the gun on a National Academy of Sciences report on forensic DNA testing, due later this summer. But congressional staff have been consulting with the academy, so there should be no major conflicts between the bills' provisions and the academy's recommendations. A far less extensive bill on forensic DNA testing was introduced into the House earlier this year by Frank. Horton.(Bepublican, New. Y.srk, , Rut. as Edwards and Simon are chairmen of House and Senate subcommittees that are responsible for the application of forensic science, the new bills should carry more weight. discrimination rules

\title{
Washington
}

Regulations due to be published next month could allow US employers to discriminate against job applicants on the basis of their genetic make-up. To avoid this possibility, Nancy Wexler, who chairs the US genome project committee dealing with the ethical, social and legal implications of genome research, will this week ask the National Institutes of Health (NIH) to press for changes to the proposed rules.

The regulations in question were drafted earlier this year by the Equal Employment Opportunity Commission (EEOC). Their purpose is to implement the 1990 Americans with Disabilities Act - legislation supposed to outlaw discrimination against job applicants on grounds of disability.

The EEOC regulations state that employers should not decide whether to hire a person on the basis of medical tests that have no bearing on that person's ability to do the job. But the regulations, as they were drafted, would allow employers to conduct tests that are not job-related, once a conditional offer of employment has been made. Because employers are not bound to reveal which medical tests they have done or why an offer of employment has been withdrawn, the regulations could do nothing to stop employers determined to discriminate.

This is a major concern in the case of genetic screening, because it may be possible in future to identify a whole suite of genes that either cause disease, or confer a high susceptibility to particular health problems. The worry is that, to minimize their health care provision costs, some employers will screen for these genes in order to exclude job applicants who are more likely to become ill. "The regulations open up some loopholes that were closed by the Act," says Eric Juengst, from the National Center for Human Genome Research.

Wexler, who is at the Columbia College of Physicians and Surgeons, wants employers restricted to conducting medical tests that are directly job-related, and hopes to convince the NIH to use its weight to secure changes to the EEOC regulations at this week's meeting of the US genome project's advisory committee.

The final regulations will be published next month, but will not come into force for another year. Mark Rothstein, director of the Health Law and Policy Institute at the University of Houston, says that when the Act was passed, there was little debate of the future impact of. genetic testing. "People are only now beginning to think about it," he says. This will be the first time that Wexler's committee has asked the NIH to intervene in the affairs of another Federal agency.

Peter Aldhous 